\title{
Evaluation on the Efficacy of Modern Fungicides against Blast and Sheath Rot of Rice
}

\author{
Y.S. Balgude*, C.R. Kshirsagar and A.P. Gaikwad
}

\author{
Mahatma Phule Krishi Vidyapeeth, Agricultural Research Station, Lonvala, Tal-Moval, \\ dist-Pune(MS),Pin-410401, India \\ *Corresponding author
}

\begin{tabular}{l} 
Ke y w o r d s \\
$\begin{array}{l}\text { Rice, Blast. Sheath } \\
\text { rot, Fungicides }\end{array}$ \\
Article Info \\
$\begin{array}{l}\text { Accepted: } \\
\text { 04 February } 2019 \\
\text { Available Online: } \\
\text { 10 March } 2019\end{array}$ \\
\hline
\end{tabular}

\section{Introduction}

Rice is the most important staple food grain for more than two billion people living in the rural and urban areas of humid and sub-humid Asia. It accounts for 30 to 50 per cent of agricultural production and 50-90 per cent of the calories consumed by these people (Hossain and Fischer, 1995). Rice provides household and national food security and generates employment and incomes for the low- income groups in these areas. However, the biotic causes like diseases and pests are causing huge losses to the rice crop. In Maharashtra, the productivity of rice is 1711 $\mathrm{kg} / \mathrm{ha}$, which is less than the national level (2517 kg/ha) (Anonymous, 2016). In Maharashtra, the rice is infected by diseases viz., leaf and neck blasts (Pyricularia grisea), leaf scald (Rhynchosporium oryzae), sheath rot (Sarocladium oryzae), brown spot (Dreschlera oryzae) and grain discolouration (Spp. of Dreschlera, Sarocladium, Pyricularia, etc.), which became the major production constraint in all rice-growing areas of the state. The average losses caused by the diseases are in between 10 to 30 per cent. However, if all these diseases appear simultaneously then huge losses ranging from 30 to 100 per cent may be caused in the susceptible varieties. 
Unfortunately, varieties are not available with multiple disease resistance. Hence, there is no alternative for management of diseases by chemicals. However, the farmers failed to control the diseases by spraying the traditional chemicals having no or less broad spectrum activity. Hence, looking in to the importance of the crop as well as severity of diseases appearing on it and need of the farmers, the trials were conducted with new broad spectrum fungicides.

\section{Materials and Methods}

The field experiments were conducted at Agricultural Research Station, Lonavala, Tal. - Maval, Dist. - Pune (MS) for consecutive two years during the kharif seasons of 2017 and 2018 in RBD design with four replications. The modern broad spectrum fungicides viz., Flusilazole $12.5 \%$ [bis(4fluorophenyl)(methyl)(1H-1,2,4-triazol-1ylmethyl)silane ] + Carbendazim 25\% SC [Benmain (2- (Methoxy- carbamoyl) benzimidazole)] ie. Lusture 37.5 SE, Azoxystrobin $18.2 \%$ [Methyl(E) - 2 - \{2 - [6 (2 - cyanophenoxy) pyrimidin - 4 yloxy]phenyl \}-3-methoxyacrylate] + Difenoconazole $11.4 \%$ w/w SC [3-chloro-4((2RS,4RS;2RS,4SR)-4-methyl-2-(1H-1,2,4triazol-1-ylmethyl)-1,3-dioxolan-2-yl)phenyl 4-chlorophenyl ether] i.e. Amistar Top 325 SC, zoxystrobin 11\% [Methyl(E) - 2 - \{2 - [6 (2 - cyanophenoxy) pyrimidin - 4 yloxy]phenyl \}-3-methoxyacrylate] + Tebuconazole $\quad 18.3 \quad \% \quad$ [(RS)-1-pchlorophenyl)-4,4-dimethyl-3-(1H-1,2,4-

triazol-1-ylmethyl)pentan-3-ol] i.e Custodia, Tricyclazole $18 \%$ [5 - methyl - 1, 2, 4 - triazol $(3,4,-\mathrm{b})(1,3)$ benzothiazole] + mancozeb 62 $\%$ [manganese ethylenebis(dithiocarbamate) (polymeric) complex with zinc salt] i.e. Merger, Zineb 68\% [Zinc ethylenebis (dithiocarbamate) (polymeric)] + Hexaconazole $\quad 4 \% \quad$ WP [2-(2,4Dichlorophenyl)-1-(1H-1,2,4-triazol-1- yl)hexan-2-ol] i.e. Avatar, Trifloxystrobin $25 \%$ [Methyl (E) - methoxyimino - $\{(\mathrm{E})-\alpha-$ $[1 \quad-\quad(\alpha, \alpha, \quad \alpha \quad-\quad$ trifluorom-tolyl $)$ ethylideneaminooxy] - o - tolyl $\}$ acetate] + Tebuconazole $50 \%$ [(RS) - 1 - p chlorophenyl) - 4, 4dimethyl - 3 - (1H - 1, 2, 4 - triazol - 1- ylmethyl) pentan- 3-ol] i.e. Nativo, Mancozeb 50\% [manganese ethylenebis(dithiocarbamate) (polymeric) complex with zinc salt] + Carbendazim $25 \%$ WS [Benmain (2- (Methoxy- carbamoyl) benzimidazole)] ie. Sprint and Fluxapyroxad $62.5 \mathrm{~g} / 1$ [3-(difluoromethyl)-1-methyl-N-[2(3',4',5'-trifluorophenyl) phenyl]pyrazole-4carboxamide] + Epoxiconazole $62.5 \mathrm{~g} / 1 \mathrm{EC}$ [(2RS,3SR)-1-[3-(2-chlorophenyl)-2,3-epoxy2-(4-fluorophenyl) propyl]-1H-1,2,4-triazole] i.e. Adexar were tested.

The highly susceptible variety of paddy, 'EK 70' was transplanted under rainfed lowland condition in plots of $5.30 \times 2.30 \mathrm{~m}^{2}$ for each of the treatment at $0.15 \mathrm{~m}$ row to row and plant to plant distance. The crop was fertilized with 50:50:50 $\mathrm{kg}$ NPK/ha as basal dose and top dressed with $50 \mathrm{~kg} \mathrm{~N} / \mathrm{ha}$ one month after transplanting. The first spray of fungicides was taken immediately after appearance of any pathogen (i.e. Pyricularia grisea) and was followed by two sprays at 15 days interval thereafter. For all diseases common spray schedule was followed. The observations for incidence / severity of different diseases were recorded as per SES scale (Anonymous, 2013) and for grain yield ( $\mathrm{kg} / \mathrm{net}$ plot) at maturity stage.

Per cent disease incidence and intensity were calculated by the formula:

Incidence $=$

No. of leaves infected X 100

Total No. of leaves examined 
$\mathrm{PDI}=$

Total numerical rating

Total No. of leaves examined X Maximum rating (i.e. 9 rating)

\section{Results and Discussion}

\section{Leaf blast}

The leaf blast data (Table 1) indicated that the treatment differences due to fungicides were statistically significant. The lowest incidence $(41.17 \%)$ and intensity (17.35\%) of leaf blast were noticed in the treatment with trifloxystrobin $25 \%$ + tebuconazole $50 \%$ $(0.04 \%)$ that showed highest disease reduction of 69.32 per cent.

While, it was followed by Azoxystrobin 11\% + Tebuconazole $18.3 \% \mathrm{w} / \mathrm{w} \quad \mathrm{SC}$ and Flusilazole $12.5 \%$ + Carbendazim $25 \%$ SC those recorded 62.27 and 58.13 per cent leaf blast reduction over control, respectively. The untreated control had significantly highest incidence of 85.51 per cent and severity of 56.56 per cent of the disease.

\section{Neck and node blasts}

The observations in Tables 1 and 2 divulge that the treatment differences in respect of neck and node blasts due to fungicides were statistically significant.

The fungicide treatment with trifloxystrobin + tebuconazole $(0.04 \%)$ had significantly least incidence of 46.50 and 35.22 per cent of neck and node blasts and thus recorded highest disease control of 48.90 and 49.96 per cent of these diseases, respectively.

This was followed by Azoxystrobin 11\% + Tebuconazole $18.3 \%$ w/w SC $(0.15 \%)$ that recorded 41.23 per cent neck blast and 43.45 per cent node blast reduction over control. The next fungicides in order of superiority were Flusilazole $12.5 \%$ + Carbendazim $25 \%$ SC and Fluxapyroxad 62.5g/1 + Epoxiconazole $62.5 \mathrm{~g} / \mathrm{l} \mathrm{EC}$, which showed 35.71 and 35.16 per cent neck blast while, 36.37 and 31.26 per cent node blast control, respectively.

The control treatment showed significantly highest neck (91.00\%) and node $(70.37 \%)$ blast incidence.

Narayana Swamy et al., (2009) also reported the most effectiveness of trifloxystrobin + tebuconazole and tricyclazole against blast of rice. In addition, the data supports the findings of (Rohilla and Singh 1999) and corroborates the findings of (Vishwanathan and Narayanaswamy 1991).

\section{Sheath rot}

The treatment differences (Table 2) due to fungicides in respect of sheath rot were statistically significant. The treatment with trifloxystrobin + tebuconazole $(0.04 \%)$ had lowest sheath rot incidence $(72.0 \%)$ and intensity $(21.45 \%)$ and thereby recorded maximum disease reduction of 66.47 per cent.

This was followed by Azoxystrobin 11\% + Tebuconazole $18.3 \%$ w/w SC $(0.15 \%)$ that recorded 76.50 per cent incidence, 23.39 per cent intensity and 63.42 per cent reduction over control.

The next fungicides in order of superiority were Fluxapyroxad $62.5 \mathrm{~g} / \mathrm{l}+$ Epoxiconazole $62.5 \mathrm{~g} / \mathrm{l} \mathrm{EC}$ and Flusilazole $12.5 \%+$ Carbendazim 25\% SC which showed 51.52 and 51.35 per cent sheath rot control, respectively. Balgude and Gaikwad (2016) also reported the most effectiveness of trifloxystrobin + tebuconazole and tricyclazole against sheath rot of rice. 


\section{Yield}

The yield data presented in Table 3 were statistically significant. The significantly highest grain yield $(28.26 \mathrm{q} / \mathrm{ha})$ and straw yield (31.42 q/ha) with 84.22 and 80.78 per cent increase was obtained in treatment with Azoxystrobin 11\% + Tebuconazole 18.3\% w/w SC, Flusilazole $12.5 \%$ + Carbendazim $25 \%$ SC, Fluxapyroxad $62.5 \mathrm{~g} / \mathrm{l}+$ Epoxiconazole 62.5g/l EC and Mancozeb 50\% + Carbendazim 25\% WS wherein, 79.69, $75.72,69.85$ and 63.14 per cent increase in grain yield and 75.06, 72.18, 66.63 and 60.33 per cent increase in straw yield was reported, respectively.

The untreated control plot yielded just 15.34 q/ha grain yield and $17.38 \mathrm{q} / \mathrm{ha}$ straw yield. . The results are exactly matching with the findings of earlier work at DRR (IIRR), Hyderabad (Anonymous, 2017) wherein they reported that the fungicide combination trifloxystrobin $25 \%$ + tebuconazole $50 \%$ reduced the diseases viz., leaf blast, neck blast, node blast and sheath rot and increased the yield of paddy to the greater extent.

Table.1 Efficacy of new fungicides against leaf and neck blasts of paddy (Pooled results of 2017 $\& 2018)$

\begin{tabular}{|c|c|c|c|c|c|c|c|}
\hline \multirow{2}{*}{$\begin{array}{l}\text { Sr. } \\
\text { No. }\end{array}$} & \multirow[t]{2}{*}{ Name of fungicide } & \multirow{2}{*}{$\begin{array}{l}\text { Dose } \\
(\%)\end{array}$} & \multicolumn{3}{|c|}{ Leaf blast (\%) } & \multicolumn{2}{|c|}{ Neck blast (\%) } \\
\hline & & & Incidence & PDI & Reduction & Incidence & Reduction \\
\hline 1 & $\begin{array}{l}\text { Flusilazole } 12.5 \%+\text { Carbendazim } \\
25 \% \text { SC }\end{array}$ & 0.10 & $\begin{array}{l}47.86 \\
\mathbf{4 3 . 7 5}\end{array}$ & $\begin{array}{l}23.68 \\
\mathbf{2 9 . 0 7}\end{array}$ & 58.13 & $\begin{array}{l}58.50 \\
\mathbf{4 9 . 9 8}\end{array}$ & 35.71 \\
\hline 2 & $\begin{array}{l}\text { Azoxystrobin } 18.2 \%+ \\
\text { Difenoconazole } 11.4 \% \mathrm{w} / \mathrm{w} \mathrm{SC}\end{array}$ & 0.10 & $\begin{array}{l}64.61 \\
\mathbf{5 3 . 6 7}\end{array}$ & $\begin{array}{l}39.90 \\
39.11\end{array}$ & 29.46 & $\begin{array}{l}76.00 \\
\mathbf{6 0 . 8 3}\end{array}$ & 16.48 \\
\hline 3 & $\begin{array}{l}\text { Azoxystrobin } 11 \%+ \\
\text { Tebuconazole } 18.3 \% \text { w/w SC }\end{array}$ & 0.15 & $\begin{array}{l}44.93 \\
\mathbf{4 2 . 0 6}\end{array}$ & $\begin{array}{l}21.34 \\
27.48\end{array}$ & 62.27 & $\begin{array}{l}53.50 \\
47.01\end{array}$ & 41.21 \\
\hline 4 & $\begin{array}{l}\text { Tricyclazole } 18 \%+\text { mancozeb } 62 \\
\% \text { WP }\end{array}$ & 0.25 & $\begin{array}{l}59.53 \\
\mathbf{5 0 . 4 9}\end{array}$ & $\begin{array}{l}36.16 \\
\mathbf{3 6 . 9 2}\end{array}$ & 36.07 & $\begin{array}{l}71.00 \\
\mathbf{5 7 . 6 4}\end{array}$ & 21.98 \\
\hline 5 & $\begin{array}{l}\text { Zineb } 68 \%+\text { Hexaconazole } 4 \% \\
\text { WP }\end{array}$ & 0.25 & $\begin{array}{l}66.61 \\
\mathbf{5 4 . 7 5}\end{array}$ & $\begin{array}{l}45.71 \\
\mathbf{4 2 . 5 1}\end{array}$ & 19.18 & $\begin{array}{l}77.50 \\
61.92\end{array}$ & 14.84 \\
\hline 6 & $\begin{array}{l}\text { Trifloxystrobin } 25 \%+ \\
\text { Tebuconazole } 50 \% \text { WG }\end{array}$ & 0.04 & $\begin{array}{l}41.17 \\
\mathbf{3 9 . 8 8}\end{array}$ & $\begin{array}{l}17.35 \\
\mathbf{2 4 . 5 8}\end{array}$ & 69.32 & $\begin{array}{l}46.50 \\
42.96\end{array}$ & 48.90 \\
\hline 7 & $\begin{array}{l}\text { Mancozeb } 50 \%+\text { Carbendazim } \\
25 \% \text { WS }\end{array}$ & 0.25 & $\begin{array}{l}59.98 \\
\mathbf{5 0 . 7 4}\end{array}$ & $\begin{array}{l}33.70 \\
\mathbf{3 5 . 4 6}\end{array}$ & 40.42 & $\begin{array}{l}62.50 \\
\mathbf{5 2 . 3 0}\end{array}$ & 31.32 \\
\hline 8 & $\begin{array}{l}\text { Fluxapyroxad } 62.5 \mathrm{~g} / 1+ \\
\text { Epoxiconazole } 62.5 \mathrm{~g} / 1 \mathrm{EC}\end{array}$ & 0.15 & $\begin{array}{l}51.51 \\
45.85\end{array}$ & $\begin{array}{l}29.00 \\
\mathbf{3 2 . 5 3}\end{array}$ & 48.73 & $\begin{array}{l}59.00 \\
\mathbf{5 0 . 2 8}\end{array}$ & 35.16 \\
\hline 9 & Control & - & $\begin{array}{l}85.51 \\
67.65\end{array}$ & $\begin{array}{l}56.56 \\
48.75\end{array}$ & -- & $\begin{array}{l}91.00 \\
\mathbf{7 3 . 1 1}\end{array}$ & -- \\
\hline & $\mathrm{SE} \pm$ & & 1.62 & 1.27 & & 2.66 & \\
\hline & $\mathrm{CD}(0.05)$ & & 4.77 & $3 . .72$ & & 7.81 & \\
\hline & $\mathrm{CV}(\%)$ & & 6.51 & 7.21 & & 9.66 & \\
\hline
\end{tabular}

The figures in the bold faces are arc sin values 
Table.2 Efficacy of new fungicides against node blast and sheath rot of paddy (Pooled results of $2017 \& 2018)$

\begin{tabular}{|c|c|c|c|c|c|c|c|}
\hline \multirow{2}{*}{$\begin{array}{l}\text { Sr. } \\
\text { No. }\end{array}$} & \multirow[t]{2}{*}{ Name of fungicide } & \multirow{2}{*}{$\begin{array}{c}\text { Dose } \\
(\%)\end{array}$} & \multicolumn{2}{|c|}{ Node blast (\%) } & \multicolumn{3}{|c|}{ Sheath rot $(\%)$} \\
\hline & & & Incidence & Reduction & Incidence & PDI & Reduction \\
\hline 1 & $\begin{array}{l}\text { Flusilazole } 12.5 \%+\text { Carbendazim } 25 \% \\
\text { SC }\end{array}$ & 0.10 & $\begin{array}{l}44.78 \\
\mathbf{4 1 . 9 8}\end{array}$ & 36.37 & $\begin{array}{l}78.00 \\
\mathbf{6 2 . 2 0}\end{array}$ & $\begin{array}{l}31.11 \\
33.86\end{array}$ & 51.35 \\
\hline 2 & $\begin{array}{l}\text { Azoxystrobin } 18.2 \% \text { + Difenoconazole } \\
11.4 \% \text { w/w SC }\end{array}$ & 0.10 & $\begin{array}{l}56.40 \\
48.69\end{array}$ & 19.86 & $\begin{array}{l}83.00 \\
66.06\end{array}$ & $\begin{array}{l}42.22 \\
\mathbf{4 0 . 5 0}\end{array}$ & 33.98 \\
\hline 3 & $\begin{array}{l}\text { Azoxystrobin } 11 \%+\text { Tebuconazole } \\
18.3 \% \text { w/w SC }\end{array}$ & 0.15 & $\begin{array}{l}39.80 \\
39.01\end{array}$ & 43.45 & $\begin{array}{l}76.50 \\
\mathbf{6 1 . 0 7}\end{array}$ & $\begin{array}{l}23.39 \\
\mathbf{2 8 . 9 1}\end{array}$ & 63.42 \\
\hline 4 & Tricyclazole $18 \%+$ mancozeb $62 \% \mathrm{WP}$ & 0.25 & $\begin{array}{l}55.97 \\
\mathbf{4 8 . 5 3}\end{array}$ & 20.47 & $\begin{array}{l}80.00 \\
63.82\end{array}$ & $\begin{array}{l}36.34 \\
\mathbf{3 7 . 0 4}\end{array}$ & 43.18 \\
\hline 5 & Zineb 68\% + Hexaconazole 4\% WP & 0.25 & $\begin{array}{l}59.77 \\
\mathbf{5 0 . 6 9}\end{array}$ & 15.07 & $\begin{array}{l}92.00 \\
\mathbf{7 6 . 2 4}\end{array}$ & $\begin{array}{l}52.34 \\
\mathbf{4 6 . 3 3}\end{array}$ & 18.16 \\
\hline 6 & $\begin{array}{l}\text { Trifloxystrobin } 25 \%+\text { Tebuconazole } \\
50 \% \text { WG }\end{array}$ & 0.04 & $\begin{array}{l}35.22 \\
\mathbf{3 6 . 3 3}\end{array}$ & 49.96 & $\begin{array}{l}72.00 \\
\mathbf{5 8 . 1 0}\end{array}$ & $\begin{array}{l}21.45 \\
27.49\end{array}$ & 66.47 \\
\hline 7 & Mancozeb 50\% + Carbendazim 25\% WS & 0.25 & $\begin{array}{l}52.13 \\
\mathbf{4 6 . 2 1}\end{array}$ & 25.93 & $\begin{array}{l}84.00 \\
\mathbf{6 6 . 6 5}\end{array}$ & $\begin{array}{l}35.78 \\
\mathbf{3 6 . 7 1}\end{array}$ & 44.05 \\
\hline 8 & $\begin{array}{l}\text { Fluxapyroxad } 62.5 \mathrm{~g} / \mathrm{l}+\text { Epoxiconazole } \\
62.5 \mathrm{~g} / 1 \text { EC }\end{array}$ & 0.15 & $\begin{array}{l}48.38 \\
44.04\end{array}$ & 31.26 & $\begin{array}{l}82.00 \\
65.78\end{array}$ & $\begin{array}{l}31.00 \\
\mathbf{3 3 . 8 0}\end{array}$ & 51.52 \\
\hline 9 & Control & - & $\begin{array}{l}70.37 \\
\mathbf{5 7 . 0 3}\end{array}$ & -- & $\begin{array}{l}96.50 \\
\mathbf{8 3 . 3 5}\end{array}$ & $\begin{array}{l}63.95 \\
\mathbf{5 3 . 1 3}\end{array}$ & -- \\
\hline & $\mathrm{SE} \pm$ & & 3.25 & & 4.35 & 2.10 & \\
\hline & $\mathrm{CD}(0.05)$ & & 9.54 & & 4.23 & 2.32 & \\
\hline & CV (\%) & & 14.19 & & 6.51 & 6.00 & \\
\hline
\end{tabular}

Table.3 Grain and straw yield influenced by management of different diseases by these fungicides (Pooled results of $2017 \& 2018$ )

\begin{tabular}{|c|c|c|c|c|c|c|}
\hline \multirow{2}{*}{$\begin{array}{l}\text { Sr. } \\
\text { No. }\end{array}$} & \multirow[t]{2}{*}{ Name of fungicide } & \multirow{2}{*}{$\begin{array}{c}\text { Dose } \\
(\%)\end{array}$} & \multicolumn{2}{|c|}{ Grain yield } & \multicolumn{2}{|c|}{ Straw yield } \\
\hline & & & q/ha & $\begin{array}{l}\text { Increase over } \\
\text { control }\end{array}$ & q/ha & $\begin{array}{c}\text { Increase } \\
\text { over control }\end{array}$ \\
\hline 1 & Flusilazole $12.5 \%+$ Carbendazim $25 \%$ SC & 0.10 & 26.96 & 75.72 & 29.93 & 72.18 \\
\hline 2 & Azoxystrobin $18.2 \%$ + Difenoconazole $11.4 \%$ w/w SC & 0.10 & 23.00 & 49.90 & 25.56 & 47.07 \\
\hline 3 & Azoxystrobin $11 \%$ + Tebuconazole $18.3 \%$ w/w SC & 0.15 & 27.57 & 79.69 & 30.43 & 75.06 \\
\hline 4 & Tricyclazole $18 \%+$ mancozeb $62 \% \mathrm{WP}$ & 0.25 & 24.36 & 58.80 & 26.99 & 55.29 \\
\hline 5 & Zineb $68 \%+$ Hexaconazole $4 \% \mathrm{WP}$ & 0.25 & 20.48 & 33.51 & 23.42 & 34.75 \\
\hline 6 & $\begin{array}{l}\text { Trifloxystrobin } 25 \%+\text { Tebuconazole } 50 \% \\
\text { WG }\end{array}$ & 0.04 & 28.26 & 84.22 & 31.42 & 80.78 \\
\hline 7 & Mancozeb 50\% + Carbendazim 25\% WS & 0.25 & 25.03 & 63.14 & 27.87 & 60.33 \\
\hline 8 & Fluxapyroxad $62.5 \mathrm{~g} / \mathrm{l}+$ Epoxiconazole $62.5 \mathrm{~g} / \mathrm{l}$ EC & 0.15 & 26.06 & 69.85 & 28.96 & 66.63 \\
\hline 9 & Control & - & 15.34 & -- & 17.38 & -- \\
\hline & $\mathrm{SE} \pm$ & & 1.25 & & 1.52 & \\
\hline & $\mathrm{CD}(0.05)$ & & 3.67 & & 4.47 & \\
\hline & $\mathrm{CV}(\%)$ & & 10.37 & & 11.29 & \\
\hline
\end{tabular}

The figures in the bold faces are arc sin values 
In conclusion, three sprays of fungicide combination viz., trifloxystrobin 25\%+ tebuconazole 50\% @ 0.04 per cent at 15 days interval starting first spray immediately after disease appearance were found to be most effective in management of leaf blast, neck blast, node blast and sheath rot diseases and thereby enhancing the grain yield in paddy. This was followed by Azoxystrobin 11\% + Tebuconazole $18.3 \%$ w/w SC and Flusilazole $12.5 \%$ + Carbendazim 25\% SC.

\section{References}

Anonymous. 2017. Disease Management Trials:Evaluation of fungicides against location specific diseases. DRR Annual Progress Report 2017, Vol. 2 - Plant Pathology: $3.87-3.104$

Anonymous. 2013. Standard Evaluation System for Rice (SES). $5^{\text {th }}$ Edition. International Rice Research Institute, Philippines. Pg: 52.

Anonymous. 2016. http://drdpat.bih.nic.in/Downloads/State wise-APY-of-Rice-2011-12-to-201516.pdf
Balgude, Y. S. and A.P. Gaikwad. 2016. Evaluation on the Efficacy of Modern Fungicides against Rice Diseases. Journal of Rice Research 2016, Vol 9( 1):53-57

Hossain M and Fischer K. 1995. Rice research for food security and sustainable agricultural development in Asia: achievements and future challenges. Geo Journal 35: 286-298.

Narayana Swamy $H$, Syed Sannaulla and Dinesh Kumar M. 2009. Evaluation of new fungicides against rice blast in Cauvery Delta. Karnataka Journal of Agricultural Sciences 22(2): 450-451.

Rohilla R and Singh US. 1999. Mode of action of carpropamid against rice blast caused by Magnaporthe grisea (Hebert). Journal of Mycology and Plant Pathology 29: 159.

Vishwanathan $\mathrm{R}$ and Narayanaswamy $\mathrm{P}$. 1991. Occurence of resistance in rice pathogen to fungicides. Indian Journal of Mycology and Plant Pathology 21: 63-65.

\section{How to cite this article:}

Balgude, Y.S., C.R. Kshirsagar and Gaikwad, A.P. 2019. Evaluation on the Efficacy of Modern Fungicides against Blast and Sheath Rot of Rice. Int.J.Curr.Microbiol.App.Sci. 8(03): 83-88. doi: https://doi.org/10.20546/ijcmas.2019.803.013 